\title{
The Effect of Four Square Step Excercise towards the Fall Risk in Elderly at PSTW Wana Seraya Denpasar 2019
}

\author{
Desak Gede Nanda Amaria Dewi ${ }^{1}$, Sang Ayu Ketut Candrawati ${ }^{1}$, \\ Ni Kadek Muliawati ${ }^{1}$ \\ ${ }_{1}^{1}$ Program Studi Keperawatan STIKes Wira Medika Bali \\ Jalan Kecak No.9A, Tonja, Kec. Denpasar Utara, Kota Denpasar, Bali \\ Email: nandaamariadewi@gmail.com
}

\begin{abstract}
Abstrak
Lansia mengalami berbagai macam perubahan akibat proses menua salah satunya yaitu pada sistem muskuloskeletal yang mengakibatkan lansia rentan terhadap jatuh dan bila tidak diatasi akan dapat mengakibatkan cedera pada lansia bahkan dapat mengakibatkan kematian. Salah satu cara untuk menurunkan tingkat risiko jatuh pada lansia yaitu dengan melakukan latihan keseimbangan khususnya latihan four square step yang tidak hanya melatih kekuatan otot lansia namun juga melatih koordinasi visual lansia. Tujuan penelitian ini adalah untuk mengetahui pengaruh latihan four square step terhadap risiko jatuh lansia. Penelitian ini mengguanakan desain pre eksperimen one group pre tets and post test without control group. Penelitian dilakukan di PSTW Wana Seraya Denpasar dengan jumlah sampel 15 responden yang dipilih melalui teknik purposive sampling. Hasil: Hasil penelitian risiko jatuh lansia sebelum latihan four square step sebanyak 12 responden (80\%) berisiko jatuh sedang dan tiga responden (20\%) berisiko jatuh tinggi sedangkan setelah latihan sembilan responden (60\%) berisiko jatuh sedang dan enam responden $(40 \%)$ berisiko jatuh rendah. Hasil uji statistik wilcoxon signed rank test didapatkan $p$ value $=0,003<\alpha 0,005$ yang berarti ada pengaruh latihan four square step terhadap risiko jatuh lansia. Diskusi: Berdasarkan hasil penelitian bahwa latihan four square step merupakan latihan yang efektif untuk menurunkan risiko jatuh lansia karena latihan ini ringan dan mudah dilakukan oleh lansia secara mandiri, maka diharapkan latihan four square step dapat diterapkan sebagai salah satu metode untuk menurunkan risiko jatuh lansia baik di panti maupun di masyarakat.
\end{abstract}

Kata kunci : lansia, latihan four square step, risiko jatuh

\section{Abstract}

Elderly undergoes various changes due to the aging process, one of them is the musculoskeletal system which results in the elderly being vulnerable to falls and if not be treated, it can cause injury to the elderly and even death. One way to reduce the level of fall risk in elderly is to do balance exercises, especially four square step exercises which is not only train the muscle strength of elderly but also train the visual coordination. The purpose of this study was to determine the effect of four square step exercises on the fall risk in elderly. This study used a design of pre-experimental one group pre-test and posttest without control group. The study was conducted at PSTW Wana Seraya Denpasar. The respondens in this study selected through purposive sampling technique. Among 36 elderly who living at PSTW Wana Seraya Denpasar, there were 17 people who met the inclusion and exclusion criteria. After calculating the sample, there were 15 samples were obtained. The results of the study, the fall risk in elderly before four square step exercise were 12 respondents (80\%) at moderate level and three respondents (20\%) at high level. After training, nine respondents (60\%) had a moderate fall risk and six respondents (40\%) 
had low fall risk. Based on the results of Wilcoxon signed rank test statistical test, it was obtained $p$ value $=0.003<\alpha 0.005$ which means there is an influence of four square step exercises towards the fall risk in elderly. Based on the results of the study, the four square step exercise is an effective exercise to reduce the fall risk in elderly because it is a light exercise which is easily carried out by the elderly independently. This exercise is recommended to be applied as a method to reduce the fall risk in elderly.

Key Words: elderly, four square step exercise, fall risk

Article info:

Article submitted on March 05, 020

Articles revised on May 07, 2020

Articles received on June 15, 2020

DOI: $h$ ttp://dx.doi.org/10.21927/jnki.2020.8(2).100-107

\section{INTRODUCTION}

The increase of life expectancy and increase the elderly population is a sign of success in country's development (1). An article of Kemenkes RI "Indonesia Enters Aging Population Period" states that Indonesia is entering an aging population period, it is estimated that the number of elderly people will increase from 18 million (7.56\%) in 2010 to 25,9 million people $(9.7 \%)$ in 2019 , and in 2035 is expected increase to 48.2 million people $(15.77 \%)$. Various kinds of health problems will occur due to an increase in the number of elderly. One of them is a weakening in the function of various body systems due to the aging process that makes elderly being vulnerable to a variety of health problems (3). According to Setiabudi, one of the health problems that occur in the elderly is a change of the musculoskeletal system such as the form of morphological changes, weakening of muscle function in lower limb, muscle strength, endurance, coordination, and limited range of motion which causes the elderly cannot maintaining the body balance (4).

Burns, E \& Kakara, R in the Morbidity and Mortality Weekly Report (MMWR) Centers for Disease Control and Prevention (CDC) state that in the United States falling is the highest cause of death due to injury at age $\geq 65$ years and the incidence continues to increase (5).
The average death caused by falls at the age of $\geq 65$ years increased $31 \%$ from $2007-2016$ and reported that one of four elderly people aged $\geq 65$ falls every year, then the number of visits to emergency departments due to falls is estimated at 3 million per year. Research in China states that the incidence rate of falls at the age of $60-99$ reached $41.5 \%$ and is more common in women than men, the percentage of injuries caused by falls is $56.3 \%$, estimated $35 \%$ undergo hospitalization, $19 \%$ had fractures, and $27.6 \%$ recovered more than 30 days (6).

Riskesdas Results reported the proportion of falls injuries in Indonesia increased from $7.5 \%$ in 2007 to $8.2 \%$ in 2013 and $9.2 \%$ in 2018 , whereas the prevalence of injury in the Bali province reached $8.8 \%$. The prevalence of injury due to falls in the elderly aged 65-74 years was $8.1 \%$ and over by $9.2 \%$ in elderly aged 75 years(7). Incidents of falls in Indonesia were recorded that from 115 elderly in nursing home, 30 of them or approximately $43.47 \%$ experienced a fall (3). Ideally, the falling frequency of elderly in 1 year occurs 1-2 times, but the fact is that the falling frequency that occur in nursing homes elderly is on the average of three times more common. Another study with a retrospective design found that $3 \%$ of the elderly who visited the Emergency Department at a hospital in Bali were caused by a fall (8). Fall can result various 
types of injuries both physical and psychological damage. The most feared physical damage is a hip fracture, while the psychological impact that may arise is shock after falling and fear of falling again so that the elderly restrict their daily activities or fall phobias. Elderly who has experienced of fall and hospitalized can occur the possibility of death (9).

Based on the description, it is necessary to prevent the falls risk in elderly because if fall has occurred, it will definitely cause complications. Even mild accident can still burden the elderly condition. Nurkuncoro's research states that prevention of fall risk in elderly can be done by doing balance exercises that helping to increase muscle strength in the lower limbs (legs) and to improve the vestibular system/body balance (10). There are many balance exercises for the elderly that have been widely studied and effective to reduce the fall risk. Rohayaniand Ayunialaksmitha research on balance training in elderly states that four square step exercise is more effective in reducing the fall risk in elderly compared to elderly exercise and balance exercise $(11,12)$. State that four square step exercises can reduce the fall risk in elderly because it is a structured physical activity that can train muscles, joints, and train the coordination of the visual system on changed of the environment condition. This exercise combines physical activity movements between moving forward, backward, left and right sides. The movements are very easy and the elderly can do this excercise independently. The study shows that four square step exercises have validity and reliability in reducing the fall risk in elderly because this exercise increases improvements in motor centers and cortical centers that affect the vestibular ratio and directional control, accelerate information processing and psychomotor processes to perform rapid steps in various situations, and can maintain direction when tripping or slipping so that it helps prevent falls (13).
The preliminary study by researchers in July 2019 at PSTW Wana Seraya Denpasar through documentation studies obtained data of elderly living in PSTW are 36 elderly consisting of 28 women and 8 men where 11 of them were in isolation due to illness. The results of researchers' observations on the elderly in PSTW Wana Seraya Denpasar found that $50 \%$ of the elderly had unbalanced walking styles, poor posture when walking, seemed unsteady when walking. There are five elderly people who walk with walking aids, two people who use wheelchairs, and there are five people who are bed rest, while there is one person who looks tremor and stiff when walking. Researchers measure the fall risk in elderly using time-up and conducted test with the results shoed that from 13 elderly in PSTW Wana Seraya Denpasar, there were $7.7 \%$ with a normal value/no fall risk, $53.8 \%$ with a mild fall risk, $30.8 \%$ with moderate fall risk, and $7.7 \%$ with a high fall risk.

Based on the description, researchers are interested in conducting research with the aim to determine the effect of four square step exercises towards the fall risk in elderly at PSTW Wana Seraya Denpasar.

\section{MATERIALS AND METHODS}

This research used a pre-experimental one group pre-test and post-test without control group design. This research was conducted at PSTW Wana Seraya Denpasar on 30 September to 26 October 2019. The respondens in this study selected through purposive sampling technique. Among 36 elderly who living at PSTW Wana Seraya Denpasar, there were 17 people who met the inclusion and exclusion criteria. After calculating the sample, there were 15 samples were obtained. This study uses two variables, four square step exercise as the independent variable and the fall risk in elderly as the dependent variable. Four square step exercises are special exercises to increase leg muscle 
strength and improve body balance using the four planes by stepping straight forward, then to the right side, backward, stepping to the left side, then returning to the right side, to forward, stepping to the left side, and retreating back to its original position, which is repeated for 15 minutes with a frequency of exercise twice a week in four weeks observed by using the four square step exercise check list. The fall risk in elderly before and after the four square step exercise is measured using a time up and conducted test that is measuring the time the elderly need to walk from a sitting position, then walk as far as 3 meters then circle the marker and walk again until sitting again in the seat. Initially recorded using pre-test and post-test observation sheets where the fall risk is normal if the time obtained is $<10$ seconds, the low fall risk if the time obtained is $10-19$ seconds, the moderate fall risk if the time obtained is $20-29$ seconds, and the high fall risk if the time obtained is $\geq 30$ seconds.

Pre-test was done on the first day of training by measuring the fall risk in elderly before four square step exercises, then the exercise was done twice a week for 15 minutes for four weeks, and on the last day a post test was done by measuring the fall risk in elderly after exercise. Pre and post test results were recorded in an observation sheet to be processed, presented and analyzed to obtain research conclusions. The data obtained in this study were coded R1 and so on up to R17 for the respondent number. The age of the respondent was given code 1 for age 60-74 years, code 2 for ages 75-90 years, and code 3 for ages $>90$ years. The gender of the respondent was given code 1 for male gender and code 2 for female gender. Fall risk of respondents were given code 1 for normal values / no fall risk, code 2 for low fall risk, code 3 for moderate fall risk, and code 4 for high fall risk. The data in this study are presented in the form of a frequency distribution of respondents based on the age of the respondent, gender, data on fall risk in elderly before and after the four square step exercise which is described in terms of the number (frequency) and percentage (\%). Analysis of the data used was non-parametric data analysis, namely Wilcoxon signed rank, where the results of the $p$ value obtained will be compared with $\alpha 0.05$, if the calculation results obtained $p$ value $\leq 0.05$, it can be concluded that there is an effect of four square step exercises on fall risk in elderly.

\section{RESULTS AND DISCUSSION}

The characteristics of the research subjects based on age and gender obtained the following results:

Based on the table 1 the majority of respondents were aged 75-90 years, as many as 10 people or $66.7 \%$.

Table 1. Characteristics of Respondents Based on Age at PSTW Wana Seraya Denpasar

\begin{tabular}{lcc}
\hline \multirow{2}{*}{ Age } & \multicolumn{2}{c}{ Respondents } \\
\cline { 2 - 3 } & frecuency $(\mathbf{n})$ & Precentage $(\%)$ \\
\hline $60-74$ & 4 & 26,7 \\
$75-90$ & 10 & 66,7 \\
$>90$ yo & 1 & 6,7 \\
\hline Total & 15 & 100 \\
\hline
\end{tabular}

Based on the table 2, the majority of respondents were female, as many as 10 people or $66.7 \%$.

Table 2. Characteristics of Respondents Based on Gender at PSTW Wana Seraya Denpasar

\begin{tabular}{lcc}
\hline \multirow{2}{*}{ Gender } & \multicolumn{2}{c}{ Respondents } \\
\cline { 2 - 3 } & Frecuency (n) & Precentage (\%) \\
\hline Male & 5 & 33,3 \\
Female & 10 & 66,7 \\
\hline Total & 15 & 100 \\
\hline
\end{tabular}

The results of the study on fall risk in elderly at PSTW Wana Seraya Denpasar before the four square step exercise show that from 15 respondents, there were 12 people or $80 \%$ at moderate risk and three people or $20 \%$ at high risk 
Table 3. Fall Risk in Elderly before Four Square Step Excercise

\begin{tabular}{lcc}
\hline \multirow{2}{*}{ Fall Risk } & \multicolumn{2}{c}{ Respondents } \\
\cline { 2 - 3 } & Frecuency (n) & Percentage (\%) \\
\hline Moderate & 12 & 80 \\
High & 3 & 20 \\
\hline Total & 15 & 100 \\
\hline
\end{tabular}

The results of the study on fall risk in elderly at PSTW Wana Seraya Denpasar after the four square step exercise show that from 15 respondents, there were 9 people or $60 \%$ at moderate risk and six people or $40 \%$ at low risk.

Table 4. Fall Risk in Elderly after Four Square Step Exercises

\begin{tabular}{lcc}
\hline \multirow{2}{*}{ Fall Risk } & \multicolumn{2}{c}{ Respondents } \\
\cline { 2 - 3 } & Frecuency (n) & Percentage (\%) \\
\hline Low & 6 & 40 \\
Moderate & 9 & 60 \\
\hline Total & 15 & 100 \\
\hline
\end{tabular}

Based on the table above the average fall risk in elderly before four square step exercise is 3.20 greater than the average fall risk in elderly after four square step exercise (2.60) where there are nine respondents who have decreased fall risk after four square exercise step, there are no respondents who have an increased fall risk after exercise, and there are six respondents having the same fall risk after exercise. The results of data analysis using the Wilcoxon Signed Ranks Test showed $p$ value of $0.003<0.005$ means that $\mathrm{Ho}$ is rejected and $\mathrm{Ha}$ is accepted, so it can be concluded that there is an effect of four square step exercises on the fall risk in elderly before and after exercise. In other words, there is a decrease of fall risk in elderly after four square step exercise.

The results showed that the fall risk in elderly of PSTW Wana Seraya Denpasar before the four square step training was mostly $80 \%$ at moderate risk and $20 \%$ at high risk with the average of fall risk was 3.20. After four square step training, it turned to $60 \%$ at moderate risk and $40 \%$ at low risk with the average of fall risk was 2.60 . This shows that there is a decrease in the average of fall risk in elderly after the four square step exercise, from 3.20 to 2.60 where there are 9 respondents who have decreased in fall risk, no respondent has an increased in fall risk, and six respondents with the same fall risk. Furthermore, the Wilcoxon signed rank test statistical results obtained $p$ value $0.003<\alpha 0.005$ which means there is an influence of four square step exercises on the fall risk in elderly.

The results of the study are in line with Setiabudi's statement that the elderly are a vulnerable group to impaired body balance because of the pathological process and aging process so they are very risking to fall. One of the health problems that occur in the elderly is a change in the musculoskeletal system in the form of changes in morphology and muscle function that decreased muscle strength of the lower extremities, endurance, coordination and limited range of motion which causes the elderly to experience disruption in maintaining body balance. Sherwood (14) stated that the process of muscle degeneration due to the aging process results in decreasing elderly activities which can have an impact on muscle atrophy. It is rarely used due to reduced activity wherein the actin and myosin content in the muscle will be reduced, muscle fibers shrink and muscle mass decreases causing the elderly unable to maintain balance and has risk of falling.

The good, correct and regular physical exercise and exercises that are appropriate to the level of health, physical activity level, and

Table 5. Results of Data Analysis on Fall Risk in Elderly Before and After the Four Square Step Exercise

\begin{tabular}{lcccccc}
\hline & \multicolumn{2}{c}{ Average } & \multicolumn{3}{c}{ Rank } & \multirow{2}{*}{ p-value } \\
\cline { 2 - 6 } & Pre & Post & Negative rank & Positif rank & Ties & \\
\hline Risk of falling & 3,20 & 2,60 & $9^{\mathrm{a}}$ & $0^{\mathrm{b}}$ & $6^{\mathrm{c}}$ & 0,003 \\
\hline
\end{tabular}


fitness level of each individual can increase strength of elderly muscles. The exercise is intended to help increase muscle strength in the lower limbs and to improve the vestibular system/balance of the body so the elderly can maintain their body stable and prevent falls. It is also to make the elderly stand up to optimize their abilities and avoid the effects caused by their inability. The brain, muscles and bones work together to maintain body balance in order to stay balanced and prevent falls (10). Four square step not only to treat muscles and joints but also the coordination of the visual system to environmental conditions. The movements in this exercise involve changes in eyes movements due to head movements when moving where changes in the vision environment trigger bodily imbalances, so that intensive training will make the eyes and head accustomed to environmental changes due to movement, the elderly body will be in a balanced position to prevent falls(15).

Stated the four square steps exercise is a balance exercise to increase vestibular and postural muscle activation. This exercise is carried out on four areas that use a pattern of foot steps forward, backward, tilt left and right as to activate the body's multisensory to be balanced so that the body does not fall, with the adaptation of such conditions then activates the improvement of the motor and cortex center. The improvements that occur affect the vestibular and speed of control, as well as increase the speed of information processing to take appropriate and fast steps under any circumstances to help balance and prevent falls. This exercise can be done indoors so it is certainly more beneficial than walking outdoors which is less beneficial for falling prevention and also unsafe for elderly people. This exercise is suitable for elderly because it can improve balance, prevent fear of falling, and improve health status in the elderly (16).

The results of this study are supported by Nurkuncoro research in the elderly at PSTW
Yogyakarta Budhi Luhur Kasongan Bantul where before performing balance training there were 20 elderly $(100 \%)$ had fall risk and after doing balance training 18 elderly (90\%) found had no fall risk which can be concluded that there is an effect of balance training on the fall risk with the Wilcoxon statistical test results showing a significance value of 0,000 $(p<0.05)(10)$. That examines the effect of core stability exercise on the fall risk in elderly in PSTW Gau Mabaji Gowa using pre experimental methods with one group pretest postetst design with the results of the study indicate that there is an effect of providing core stability exercise on the fall risk in elderly after statistical tests using the Wilcoxon test with a significant value of $p<0.001(p<0.05)$ (17). Putri also conducted a study on the effect of a four square step test on the reduction of fall risk in elderly at Posyandu and Nursing Home Aisyah by using pre-post with control design with Tinnety Performance Observation Mobility Assessment as measurement instruments and a reduction in the fall risk fell on the treatments group that had been tested with Wilcoxon test and obtained $p$ value 0,000 (16).

Based on the three journals when compared with the results of this study, the p-value obtained by researchers is still quite high, it can be caused by several things including in Nurkuncoro's research most $(70 \%)$ of respondents are under 75 years old and Putri's research $93.3 \%$ were under 75 years old, whereas in this study most $(66.7 \%)$ were aged $75-90$ years, which made it difficult for researchers to reduce the fall risk significantly because the physical condition of the elderly who are already too old. Furthermore, in Magdalena's study, the core stability training was conducted three times a week for four weeks while in this study the exercise was only conducted twice a week for four weeks so the results obtained by Magdalena's study were better than this study because of the more routine training schedule. Nurkuncoro and Magdalena's research used balance and core stability interventions that have 
more movement to get more effective results in reducing the fall risk which is difficult to apply in this study because the age of respondents. The researchers believe that four square step exercise which has simple movements, easy to understand, and can be done independently by respondents is an appropriate exercise applied for the elderly in PSTW.

Researchers believe that four square step exercise is suitable for the elderly because it is a physical activity that is light and easy to do and does not burden the elderly. The elderly can do it independently and do not need a special place or can be done indoors. This exercise can improve the coordination of elderly movement in all directions so that it can improve the response while moving, improve the balance, and prevent falls in the elderly.

\section{CONCLUSION AND RECOMMENDATION}

Based on the results of this study, it can be concluded that before the four square step exercise was conducted towards the 15 respondents in PSTW Wana Seraya Denpasar, there were 12 people or $80 \%$ at moderate risk and 3 people or $20 \%$ at high risk. Whereas after four square step training, 9 people or $60 \%$ at moderate risk and 6 people or $40 \%$ at low risk. The results of data analysis using the Wilcoxon Signed Ranks Test found that there was a decrease in the average of fall risk in elderly after training, from 3.20 to 2.60 where there were nine respondents who experienced a decreased fall risk after four square step exercises, none of the respondents experienced increased of fall risk after exercise, and there were six respondents having the same fall risk after exercise. The results of $p$ value 0.003 , where $p$ value $<0.005$, means that $\mathrm{Ho}$ is rejected and $\mathrm{Ha}$ is accepted, so it can be concluded that there is an influence of four square step exercises on the fall risk in elderly after exercise (there is a decrease of fall risk in elderly after four square step exercises).
Based on the study result the researcher would like to suggest the gerontik nurse to implement the four square step exercise as one of the nursing interventions in the elderly to prevent and reduce the incidence of falls in elderly patients. Furthermore, it is expected that PSTW Wana Seraya Denpasar establishing a policy to integrate the four square step exercise program into the elderly health program. Besides, respondents are expected to be able to continue training regularly to prevent falls. The last but not least, the results of this study are expected to be a reference for other researchers who wish to examine the fall risk in elderly and four square step exercises using different research designs such as using quasi experiments, using control groups, or continuing this research by controlling confounding factors that become limited in this study such as the physical condition of the elderly, the use of drugs that might affect the results of research, environmental conditions, the use of walking aids or footwear.

\section{REFERENCES}

1. Pusat Data dan Informasi Kementrian Kesehatan RI. Analisis Lansia di Indonesia Tahun 2017. Jakarta : Kemenkes RI, 2017.

2. Kemenkes RI. Indonesia Masuki Periode Aging Population. 2019. (cited 9 Juli 2019) Available from: http://www.depkes.go.id/ article/view/19070500004/indonesia-masukiperiode-aging-population.html

3. Darmojo. Buku Ajar Geriatri (IImu Kesehatan Usia Lanjut) Edisi ke-4. Jakarta: Balai Penerbit FKUI, 2010.

4. Setiabudi. Menjaga Keseimbangan Kulaitas Hidup pada Lanjut Usia. Panduan Gerontologi Tinjauan dari Berbagai Aspek. Jakarta: PT. Gramedia Pustaka Utama, 2005.

5. Burns, E \& Kakara, R. Deaths from Falls Among Persons Aged $\geq 65$ Years - United States, 2007-2016 Morbidity and Mortality Weekly Report (MMWR). Centers for Dissese 
Control and Prevention (CDC). 2018. (cited 12 juli 2019) Available from: https://www.cdc. $\mathrm{gov} / \mathrm{mmwr} / \mathrm{volumes} / 67 / \mathrm{wr} / \mathrm{mm} 6718 \mathrm{a} 1 . \mathrm{htm}$

6. Hong-Ying $\mathrm{Pi}$, et all. Circumstances of Falls and Fall-Related Injuries Among Frail Elderly Under Home Care in China. 2015. (cited 20 Juli 2019) Available from: https:// www.sciencedirect.com/science/article/pii/ S2352013215000642

7. Riskesdas.Laporan Nasional RISKESDAS 2018. Kementrian Kesehatan RI. Badan Penelitian dan Pengembangan Kesehatan. 2018. (cited 2 Agustus 2018) Available from: https://dinkes.kalbarprov.go.id/wpcontent/ uploads/2019/03/Laporan-

8. Suyasa, dkk. Alasan Kunjungan Lanjut Usia ke Instalasi Gawat Darurat. Laporan Penelitian. STIKES Bali. 2014.

9. Stenley, M dan Beare, P. G. Buku Ajar Keperawatan Gerontik, Edisi 2. Jakarta: Buku Kedokteran,2007

10. Nurkuncoro, I. Pengaruh Latihan Keseimbangan terhadap Risiko Jatuh pada Lansia di Panti Sosial Tresna Werdha Yogyakarta Unit Budi Luhur Kasongan Bantul. 2015. (cited 10 Juli 2019) Available from: http://digilib.unisayogya.ac.id/84/

11. Rohayani, I. Perbedaan Pengaruh Balance Exercise dan Senam Lansia di POSYANDU Lansia Wira Lestari IX Wirobrajan. Yogyakarta: Program Studi Fisioterapi Fakultas IImu Kesehatan Universitas Asyyiyah Riskesdas2018-Nasional.pdf .2017(cited 6 Juli 2019)

12. Ayunialaksmitha.Intervensi Four Square Step Lebih Efektif dalam Meningkatkan
Keseimbangan Dinamis daripada Balance Stategy Exercise pada Lansia di Kelurahan Tonja, Denpasar Timur, Bali. 2016. (cited 13 Juli 2019) Available from: https://docplayer. info/66503380-Intervensi-four-square-step. $\mathrm{html}$

13. Moore \& Barker. The Validity and Reliability Of The Four Square Step Test in Different Adult Populations: A Systematic Review. 2017. (cited 20 Juli 2019) Available from: https://www.ncbi.nlm.nih.gov/pmc/articles/ PMC5594590/

14. Suhartono. Penilaian Keseimbangan dengan Aktivitas Kehidupan Sehari-hari. Semarang: Undip, 2005.

15. Dite and Temple. A Clinical Test Of Stepping and Change Of Direction to Identify Multiple Falling Older Adult. 2012. (cited 30 Juli 2019) Available from: http://www.udel.edu/ PT/PT\%20Clinical\%20Service/Journalclub/ noacj/06_07june07/4\%20step\%20test,pdf

16.Putri, E. Pengaruh Square Step terhadap Penurunan Risiko Jatuh pada Lanjut Usia. 2018. (cited 10 Juli 2019) Available from: http://webcache. googleusercontent.com/search?q=cache:Nhz06nHkHYJ:eprints.ums.ac.id/61214/14/ NASKAH\%2520PUBLIKASI\%25281\%2529$1 \% 2520$ Erwin.pdf + \& c d = 4 \& hl = id\&ct=clnk\&gl=id

17. Magdalena. Pengaruh Core Stability Exercise terhadap Risiko Jatuh pada Lasia di PSTW Gau Mabaji Gowa. 2017. (cited 20 juli 2019) Available: http://digilib.unhas.ac.id/ uploaded_files/temporary/DigitalCollection/ 